\title{
PENGARUH INFRASTRUKTUR DASAR DAN SOSIAL TERHADAP PERTUMBUHAN EKONOMI DESA TERTINGGAL
}

\author{
NILA DEWI W. ${ }^{1)}$ \\ GUSNI $^{2)}$ \\ ${ }^{1}$ Fakultas Ekonomi, Universitas Widyatama, Bandung, Indonesia \\ ${ }^{2}$ Fakultas Bisnis dan Manajemen, Universitas Widyatama, Bandung, Indonesia \\ nila.dewi@widyatama.ac.id
}

\begin{abstract}
Abstrak
Salah satu permasalahan ekonomi yang struktural yang dihadapi dan menjadi tantangan saat ini yaitu mengenai disparitas. Hal ini ditunjukkan dengan rasio gini di provinsi Jawa Barat tahun 2016, yaitu sebesar 0,402 yang telah melampaui rasio gini Indonesia.Masih banyak ditetapkannya wilayah atau kawasan di Indonesia yang termasuk dalam daerah/desa tertinggal juga menjadi fenomena yang menunjukan telah terjadinya ketimpangan.Tantangan untuk menyediakan infrastruktur yang memadai terutama infrastruktur dasar dan sosial kemudian menjadi fokus perhatian dalam mendorong pertumbuhan ekonomi.

Oleh karena itu, pada penelitian ini penulis akan mecoba untuk menganalisis sejauh mana implikasi dari sanitasi, air bersih, listrik, pendidikan, kesehatan, dan keamanan terhadap pertumbuhan ekonomi desa tertinggal khususnya di Kabupaten Garut. Melalui pengolahan data yang diperoleh dari pendataan Potensi Desa (Podes), pendekatan analisis yang digunakan adalah berupa analisis regresi pada periode 2008, 2011 dan 2014 sehingga dapat diidentifikasi jenis infrastruktur yang paling memiliki pengaruh pada nilai output, sebagai indikator keberhasilan ekonomi desa. Hasil penelitian menunjukan bahwa hanya instrumen infrastruktur sosial yang mempengaruhi hasil output desa secara signifikan sehingga strategi yang tepat sangat diperlukan untuk sebagai rekomendasi untuk pemerintah daerah dalam rangka menciptakan pembangunan ekonomi yang inklusif.
\end{abstract}

Kata kunci: infrastruktur dasar, infrastruktur sosial, pertumbuhan ekonomi.

\begin{abstract}
One of the structural and developing economic problems today is about disparity. This is done by the ratio of the province in 2016, which is equal to 0.402 which has exceeded the ratio of Indonesia's gini. There are still many areas or regions in Indonesia that are included in the region / city which is also a phenomenon that indicates inequality. The challenge to provide adequate infrastructure, especially basic and social infrastructure, is the focus of attention in encouraging economic growth.

Therefore, in this study the author will try to analyze various things from sanitation, clean water, electricity, education, health, and economic development in Garut Regency. Through the processing of data obtained from village potential data collection (Podes), an analysis that produces regression analysis in the 2008, 2011 and 2014 periods can be used as an indicator of village economic success. The results of the study show that only social infrastructure instruments significantly influence the output of the village so that the right strategy is needed as a recommendation for local governments in order to create inclusive economic development.
\end{abstract}

Keywords: basic infrastructure, social infrastructure, economic growth

\section{Pendahuluan}

Permasalahan struktural yang menjadi isu penting dalam tujuan pembangunan nasional adalah mengenai kesenjangan antar wilayah dan kertinggalan suatu daerah.Hal ini yang kemudian menjadi perhatian khusus pemerintah dalam rangka menciptakan pembangunan yang inklusif dan berkesinambungan. Berdasarkan Peraturan Pemerintah No.78 Tahun 2014 
tentang Percepatan Pembangunan Daerah Tertinggal, yang merupakan daerah tertinggal adalah daerah kabupaten yang masyarakat serta wilayahnya kurang berkembang dibandingkan daerah lain dalam skala nasional. Suatu daerah ditetapkan sebagai daerah tertinggal berdasarkan kriteria : 1) Perekonomian masyarakat; 2) Sumberdaya manusia; 3) Sarana dan Prasarana; 4) Kemampuan keuangan daerah; 5) Aksesibilitas; 6) Karakteristik daerah.(Bappenas, 2016)

Hingga saat ini, 122 kabupaten di Indonesia masih dinyatakan tertinggal dan mayoritas merupakan kabupaten di luar Pulau Jawa.Namun, dua di antaranya berada di Jawa Barat yaitu Kabupaten Garut dan Kabupaten Sukabumi dengan indikator yang digunakan yaitu indeks pembangunan manusia dan infrastruktur (Bappenas, 2016).Mengamati data pengeluaran perkapita tahun 2016, diketahui bahwa $42.80 \%$ penduduk Kabupaten Garut berada pada golongan pengeluaran Rp 300.000-499.999 per kapita sebulan.

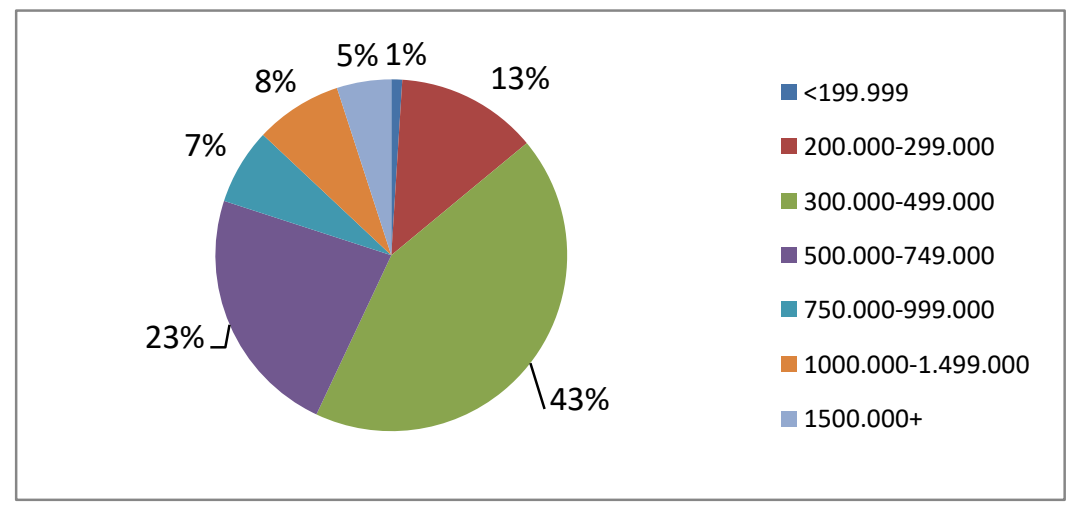

Sumber: Kabupaten Garut dalam angka 2017, data diolah

Gambar 1.Penduduk Menurut Golongan Pengeluaran Per kapita Sebulan di Kabupaten Garut 2016

Adapun, jika melihat persentase penduduk miskin sebagaimana grafik, menunjukan bahwa dari tahun ke tahun kondisinya mengalami penurunan, namun diketahui masih terdapat 11.27\% di tahun 2017 penduduk Kabupaten Garut berada di bawah garis kemiskinan, dengan garis kemiskinan sebesar Rp 256.770 per kapita per bulan..(BPS, 2017) 


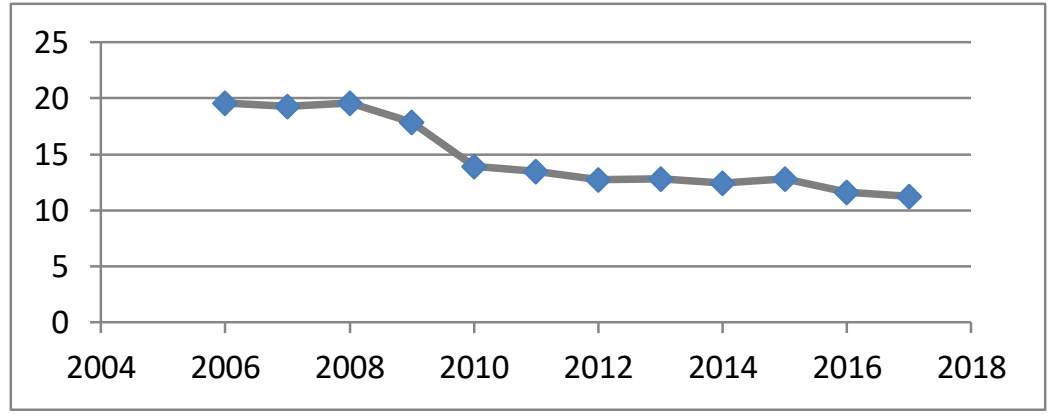

Sumber: BPS, data diolah

Gambar 2. Persentase Penduduk Miskin Kabupaten Garut

Mengacu pada kondisi diatas, kemampuan perekonomian daerah, khususnya daerah tertinggal kemudian dikaitkan dengan permasalahan belum meratanya ketersediaan infrastuktur khususnya infrastruktur.Keberhasilan ekonomi dan kualitas sosial masyarakat dinilai mampu mendukung upaya penangulangan kemiskinan (United Nations, 2011). Infrastruktur dasar berupa air bersih dan sanitasi mampu mempengaruhi secara dominan terhadap direct saving, dengan rendahnya biaya atau akses terhadap air bersih mampu berdampak pada kualitas kesehatan masyarakat (Brenneman \& Kerf, 2002). Sosial infrastruktur, seperti kesehatan dan pendidikan keduanya memiliki pengaruh secara langsung dan tidak langsung terhadap kualitas hidup masyarakat.Dampak secara langsung nya adalah mampu meningkatkan tingkat produktivitas ekonomi menuju kenaikan tingkat pertumbuhan dan pendapatan.Sosial infrastruktur juga menjadi sarana investasi berupa SDM yang membantu mendukung pemanfaatan infrastruktur fisik.(United Nations, 2011)

Melalui kebijakan desentralisasi fiskal, peran pemerintah daerah dibutuhkan untuk mendukung penyelesaian masalah ketimpangan dan mendukung percepatan pembangunan regional.Salah satu peran pemerintah dalam memfasilitasi dan mendukung pertumbuhan infrastruktur adalah dengan mengalokasikan anggaran belanja terutama untuk pembangunan dan pemeliharaan infrastruktur dasar. Beberapa kajian menunjukan bahwa ketersediaan infrastruktur yang kurang memadai merupakan masalah utama dalam meningkatkan GDP (Gross Domestic Product) sebagaimana dalam(McRae, 2015)(Esfahani, 2003). Infrastruktur 
fisik merupakan bagian dari sistem yang mendukung peranan sektor jasa yang juga memiliki kontribusi yang besar terhadap pertumbuhan ekonomi dan pengentasan kemiskinan (Ness, 2008)(Dercon \& Gilligan, 2008). Investasi berupa infrastruktur dan pertumbuhan ekonomi keduanya memiliki hubungan yang positif, selain itu pembangunan sosial dan ekonomi yang berkelanjutan mampu mengurangi angka kemiskinan dan ketimpangan (Foster \& Briceñogarmendia, 2010).

Di Indonesia, khususnya provinsi Jawa Barat beberapa persoalan yang terkait dengan pelayanan infrastruktur masih terjadi. Dengan kondisi populasi yang merupakan provinsi terbesar di Indonesia dalam hal jumlah penduduk, yaitu sebanyak 46,7 juta jiwa, (BPS, 2016) masih muncul persoalan yang terkait dengan pelayanan infrastruktur transportasi, penyediaan air bersih, pembuangan limbah, serta infrastruktur lainnya. Meski pemerintah telah berupaya memaksimalkan program penyediaan layanan sarana dan prasarana publik, namun saat ini belum menunjukan hasil yang memuaskan.Termasuk persoalan kini khususnya kondisi di desa tertinggal dinilai memiliki keterbatasan dalam ketersediaan infrastruktur dasar dan sosial.Untuk itu diperlukan kajian mengenai pembangunan kondisi sosial ekonomi di desa tertinggal dengan menganalisis peran infrastruktur dasar dan sosial untuk mewujudkan sasaran pembangunan desa tertinggal.

\section{Metode Penelitian}

\section{Model Penelitian}

Model penelitian untuk mengukur indeks infrastruktur dasar dan infrastruktur sosial setiap desa tertinggal di Kabupaten Garut, dilakukan analisis melalui model berikut: 


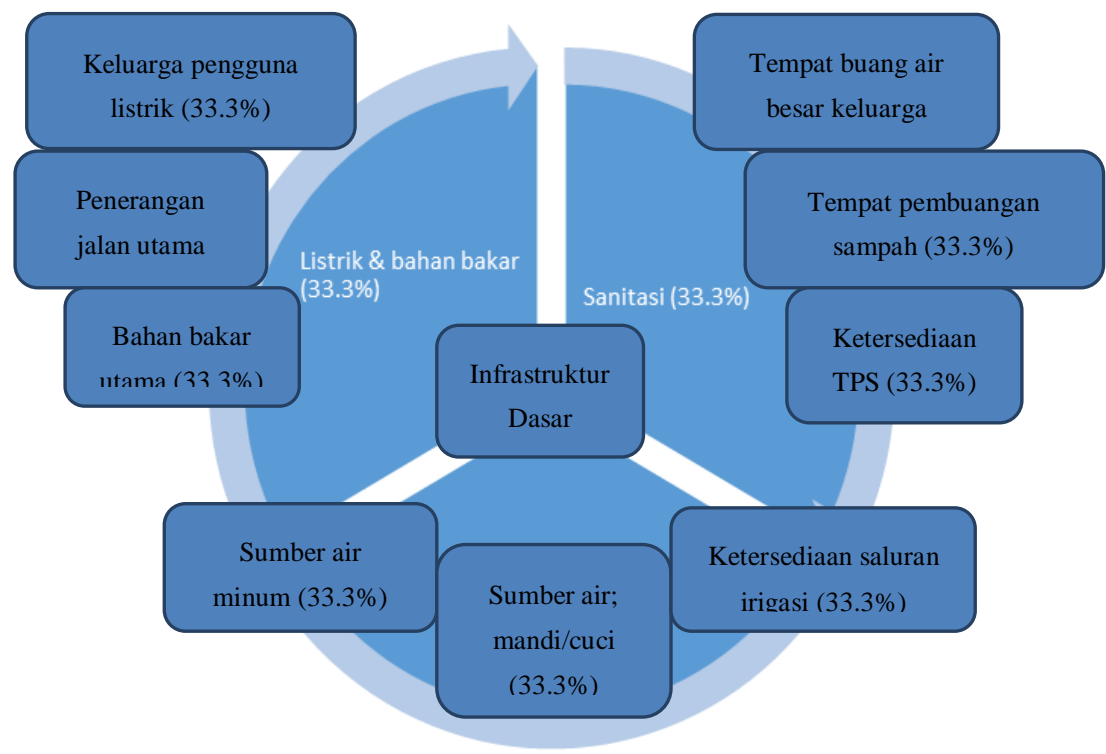

Gambar 3. Model Pengukuran Indeks Infrastruktur Dasar

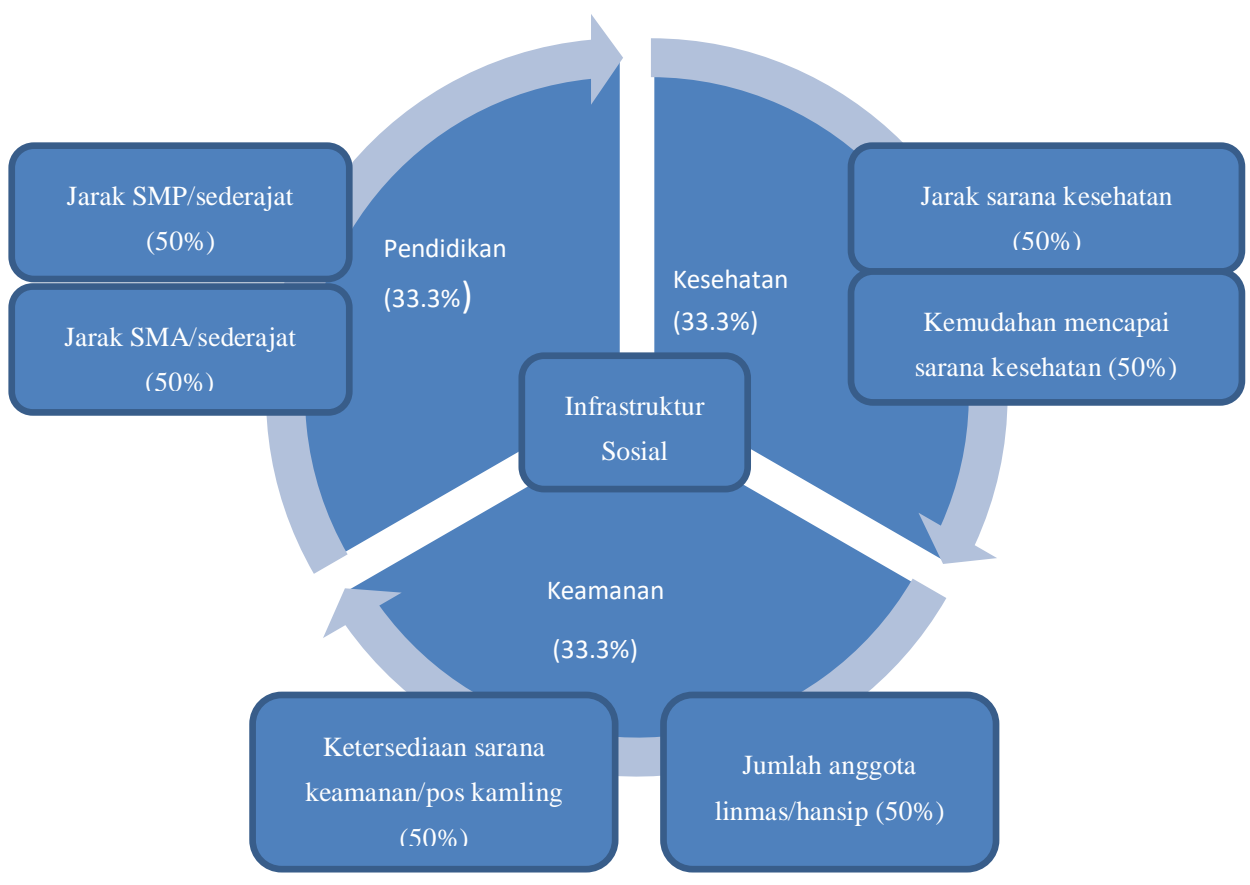

Gambar 4. Model Pengukuran Indeks Infrastruktur Sosial

Pada model diatas, untuk mengukur indeks infratruktur dasar digunakan tiga komponen yang terdiri dari listrik, sanitasi dan air yang masing-masing terdiri dari tiga sub indikator. Keseluruhan 9 sub indikator dibobot sama rata sebesar 33.3\% yang dapat merepresentasikan 
besarnya masing masing indikator. Tahap berikutnya dilakukan pembobotan kembali pada indikator listrik, air, dan sanitasi sebesar $33.3 \%$ untuk pada akhirnya memperoleh besarnya indeks infrastruktur dasar.

Untuk pengukuran indeks infrastruktur sosial, aspek pendidikan, kesehatan,dan keamanan digunakan untuk menggambarkan kondisi sosial di setiap desa. Masing-masing terdiri dari 2 sub indikator yang keseluruhannya dibobot sebesar 50\% untuk memperoleh besaran yang dapat merepresentasikan tiga indikator. Untuk memperoleh besarnya indeks infrastruktur sosial, berikutnya dilakukan pembobotan kembali pada indikator pendidikan, kesehatan, dan keamanan sebesar 33.3\%.

\section{Jenis dan Sumber Data}

Jenis data yang digunakan pada penelitian merupakan data sekunder. Data sekunder diperoleh dari pendataan Potensi desa (Podes) yang dilakukan secara rutin sebanyak 4 tahun sekali oleh Badan Pusat Statistik (BPS). Data Podes yag digunakan adalah data tahun 2008, 2011 dan 2014 di 12 desa tertinggal Kabupaten Garut. Dalam penelitian ini indikator terdiri dari instrumen infrastruktur dasar, infrastruktur sosial yang bersumber dari kuesioner Podes pada aspek perumahan dan lingkungan hidup, pendidikan dan kesehatan, serta keamanan.Berdasarkan informasi yang bersumber dari kuesioner Podes tersebut, kemudian dilakukan skoring untuk setiap komponen.Komponen infrastruktur dasar merupakan penilaian dari akses terhadap air bersih, listrik dan sanitasi. Adapun variabel berupa indeks kesehatan, pendidikan, dan keamanan merupakan proxy dari infrastruktur sosial. Sebagai dasar perhitungan pertumbuhan melalui pendekatan produksi, nilai volume usaha dari koperasi digunakan sebagai output produksi desa dimana data diperoleh dari Dinas Koperasi dan UKM Kabupaten Garut. Besarnya output menjadi indikator yang digunakan untuk melihat sejauh mana kemampuan ekonomi masyarakat dengan akses infrastruktur yang telah tersedia.

\section{Teknik Pengolahan dan Analisis Data}


Teknik pengolahan data yang digunakan dalam penelitian ini adalah sebagai berikut:

1. Menggunakan metodologi kerangka daya saing Asia Competitiveness Institute (ACI), dimana mempertimbangkan berbagai faktor yang mempengaruhi kemampuan suatu daerah untuk mencapai pembangunan ekonomi yang inklusif dalam jangka panjang (Amri, 2014). Indeks infrastruktur diperoleh dengan menggunakan data indikator air, sanitasi, listrik, pendidikan, kesehatan, dan keamanan. Skor standar yang diperoleh menunjukan kemampuan setiap desa terhadap akses infrastruktur setiap tahun nya dalam kurun waktu 2008, 2011 dan 2014.

$$
\text { Nilai standar }=\frac{\text { Nilai asli }- \text { Nilai rerata }}{\text { Standar Deviasi }}
$$

0 (nol) : sama dengan rerata

- (negatif) : di bawah rerata

+ (positif) : di atas rerata

Semakin jauhdari nol, semakin jauh pula dari rerata. (Nilai skor relatif, bukan absolut)

2. Pengolahan data melalui analisis regresi, digunakan untuk mengidentifikasi pengaruh indeks infastruktur dasar dan infrastruktur sosial terhadap nilai output desa di masingmasing desa tertinggal di Kabupaten Garut.

$$
\begin{gathered}
\mathrm{Y}=\mathbf{a}+\mathbf{b}_{1} \mathrm{BINF}+\mathbf{e} \\
\mathrm{Y}=\mathbf{a}+\mathrm{b}_{1} \mathrm{SINF}+\mathbf{e} \\
\mathrm{Y}=\mathbf{a}+\mathbf{b}_{1} \mathrm{BINF}+\mathbf{b}_{2} \mathrm{SINF}+\mathbf{e}
\end{gathered}
$$

Dimana:

Y : Nilai output

a : Konstanta

$\mathrm{b}_{1}$ : Koefisien regresi

BINF: Infrastruktur dasar

SINF: Infrastruktur sosial

e: error term

\section{Hasil dan Pembahasan}

\section{Analisis Infrastruktur Desa Tertinggal}


Berdasarkan data dari hasil pendataan potensi desa (Podes) pada tahun 2008, 2011 dan 2014 sejumlah 12 desa yang dikategorikan sebagai desa tertinggal menurut data provinsi, diperoleh hasil pemetaan sebagai berikut:

Tabel 1. Pemetaan dan Klasifikasi Indikator

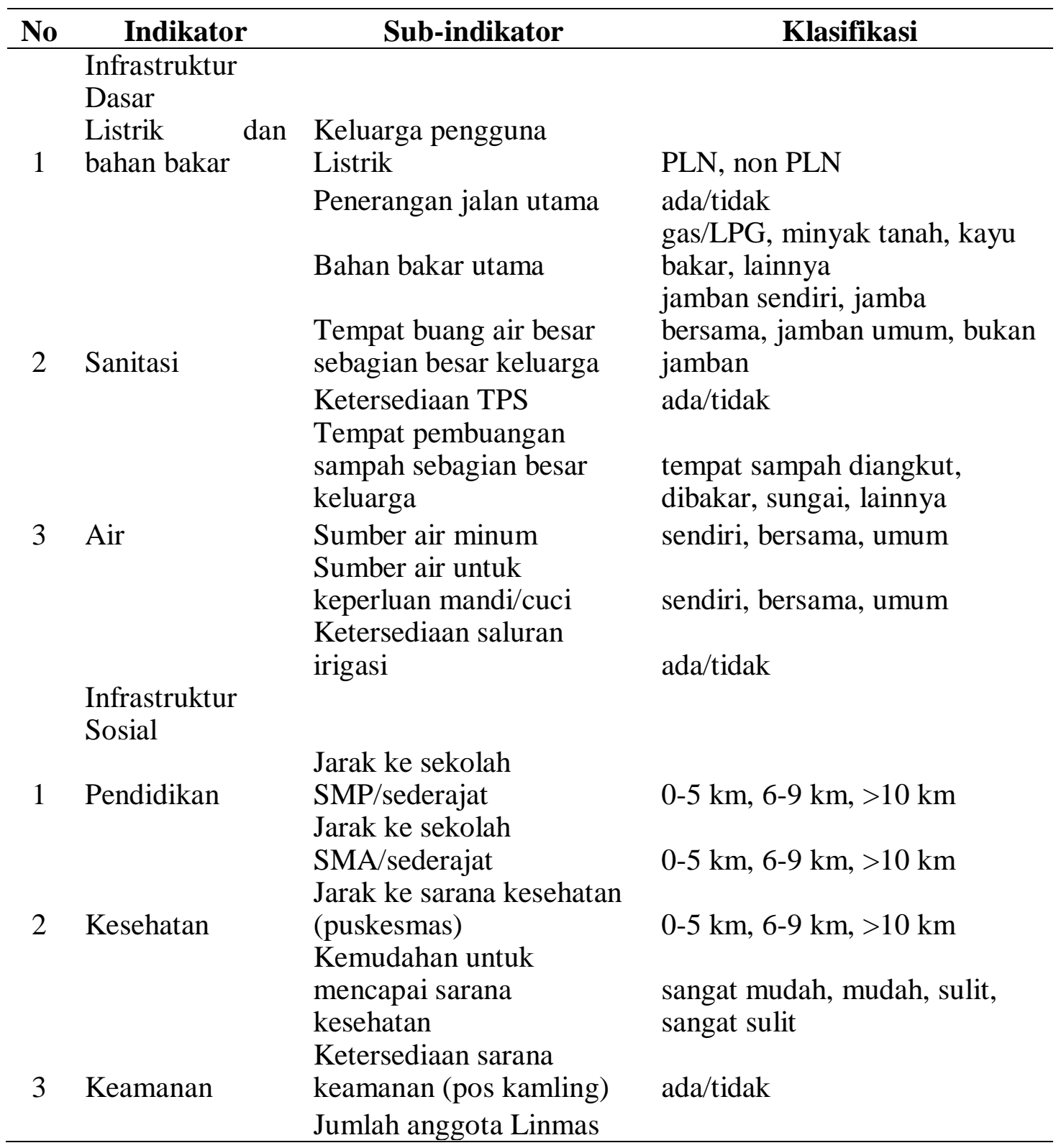

Indikator infrastruktur dasar berasal dari aspek perumahan yang terdiri dari listrik, bahan bakar utama, sanitasi, dan air. Selanjutnya komponen indikator infrastruktur sosial tediri dari fasilitas pendidikan, kesehatan, dan keamanan. Tiap sub indikator diberikan scoring sesuai dengan klasifikasi yang tersedia pada kuesioner Podes, kemudian diukur nilai standar deviasi 
yang dihitung mulai dari level sub indikator, menuju ke indikator, hingga diperoleh nilai indeks yang mewakili infrastruktur dasar. Berikut adalah hasil perhitungan skor standar dari 12 desa tertinggal yang berada di 11 kecamatan:

\section{Analisis Pengaruh Infrastruktur terhadap Nilai Output Produksi}

Adapun untuk mengidentifikasi pengaruh besarnya indeks infrastruktur dasar dan infrastruktur sosial terhadap nilai output/produksi dilakukan analisis regresi dengan hasil berikut:

Dependent Variable: Output

Method: Least Squares

Date: 09/24/18 Time: 02:38

Sample: 136

Included observations: 36

\begin{tabular}{lrlrr}
\hline \hline \multicolumn{1}{c}{ Variable } & Coefficient & Std. Error & t-Statistic & Prob. \\
\hline \hline Basic Inf. & -0.059584 & 0.274564 & -0.217013 & 0.8295 \\
Social Inf. & 0.606682 & 0.274564 & 2.209622 & 0.0342 \\
\multicolumn{1}{c}{ C } & 16.46830 & 0.242628 & 67.87478 & 0.0000 \\
\hline \hline R-squared & 0.139579 & Mean dependent var & 16.46830 \\
Adjusted R-squared & 0.087432 & S.D. dependent var & 1.523909 \\
S.E. of regression & 1.455766 & Akaike info criterion & 3.668597 \\
Sum squared resid & 69.93540 & Schwarz criterion & 3.800557 \\
Log likelihood & -63.03474 & Hannan-Quinn criter. & 3.714654 \\
F-statistic & 2.676662 & Durbin-Watson stat & 2.126393 \\
Prob(F-statistic) & 0.083701 & & \\
\hline \hline
\end{tabular}

$$
\begin{aligned}
& \mathrm{Y}=\mathbf{a}+\mathrm{b}_{1} \mathrm{BINF}+\mathrm{b}_{2} \mathrm{SINF}+\mathrm{e} \\
& \mathrm{Y}=16.468-0.059 \mathrm{BINF}+0.606 \mathrm{SINF}+\mathrm{e}
\end{aligned}
$$

Hasil menunjukan bahwa diantara kedua variabel, hanya infrastruktur sosial yang memiliki pengaruh signifikan terhadap besarnya output dan mempunyai hubungan yang positif. Adapun untuk indek sinfrastruktur dasar, tidak memiliki pengaruh yang signifikan terhadap nilai output, dan memiliki hubungan negatif. Berbeda dengan (Brenneman \& Kerf, 2002)yang menyatakan bahwa infrastruktur dasar berupa air bersih dan sanitasi mampu mempengaruhi secara dominan terhadap direct saving dalam hal ini peningkatan ekonomi. Dengan taraf signifikansi 0.1 berdasarkan hasil dapat disimpulkan juga bahwa variabel infrastruktur dasar dan sosial hanya mampu menjelaskan variabel output sebesar $13.9 \%$ dan 
sebanyak $86.1 \%$ dijelaskan oleh faktor lain di luar model. Aspek kependudukan dan faktor ekonomi seperti permodalan pada koperasi dapat disertakan pada model, hanya pada kajian ini peneliti memang lebih akan fokus pada indikator infrastruktur. Hasil analisis pengujian asumsi klasik menunjukan semua asumsi terpenuhi, pada uji normalitas diperoleh nilai probabilitas Jarque-Bera yang lebih besar dari alpha $0.1(\alpha=10 \%)$,sebesar $0.480>0.1$ sehingga disimpulkan bahwa residual terdistribusi normal. Adapun untuk asumsi multikolinearitas, hasil menunjukan nilai koefisien korelasi antar variabel independen memiliki nilai di bawah 95\%, maka dapat dikatakan tidak terjadi multikolinearitas. Berikutnya adalah uji autokorelasi, dimana dapat dilihat dari nilai Durbin Watson sebesar 2.126(DW hitung) yang lebih besar dari batas atas (du) dan kurang dari 4-du, yang artinya tidak terdapat autokorelasi. Adapun untuk uji heteroskedastisitas melalui uji Breusch-Pagan-Godfrey, diketahui nilai probabilitas F hitung sebesar 0.4522 yang lebih besar dari alpha 0.1 sehingga dapat disimpulkan tidak terjadi heteroskedastisitas.

Berdasarkan analisis diatas dapat diketahui bahwa dibandingkan infrastruktur fisik, infrastruktur sosial dalam hal ini seperti pendidikan, kesehatan dan keamanan memiliki pengaruh yang lebih besar terhadap keberhasilan ekonomi masyarakat desa. Hal ini sejalan dengan(United Nations, 2011)(Gnade, Blaauw, \& Greyling, 2017) yang mengungkapkan bahwa sosial infrastruktur, seperti kesehatan dan pendidikan keduanya memiliki pengaruh secara langsung dan tidak langsung terhadap pertumbuhan ekonomi.

\section{Kesimpulan dan Saran}

\section{Kesimpulan}

Berdasarkan rumusan masalah dan tujuan dalam penelitian ini, dari hasil analisis yang diperoleh terdapat kesimpulan sebagai berikut: Pertama,komponen infrastruktur sosial memiliki peran terhadap pertumbuhan ekonomi desa tertinggal. Hal ini dilihat berdasarkan 
hasil analisis yang menunjukan bahwa hanya komponen infrastruktur sosial seperti pendidikan,kesehatan dan keamanan yang memiliki pengaruh signifikan terhadap nilai output desa sebagai indikator capaian ekonomi desa. Tidak signifikannya pengaruh indeks infrastruktur dasar pada nilai output dapat dinilai bahwa komponen infrastruktur dasar tidak berpengaruh secara langsung terhadap keberhasilan ekonomi. Kedua, model strategi pengembangan ekonomi desa tertinggal dapat dimulai dengan investasi berbasis infrastruktur khususnya infrastruktur sosial, dimana mampu meningkatkan pertumbuhan ekonomi desa. Langkah yang dapat ditempuh adalah dengan pembangunan serta kemudahan akses terhadap sarana pendidikan mulai dari setingkat SMP/sederajat dan peningkatan fasilitas kesehatan.

\section{Saran}

Adapun saran dalam penelitian ini adalah sebagai berikut:

1. Untuk mendorong pertumbuhan ekonomi di desa tertingal kabupaten Garut, diperlukan peran strategis pemerintah untuk lebih fokus pada infrastruktur atau akses sarana pendidikan dan kesehatan. Program sinergi yang juga dapat dilakukan berikutnya adalah melalui pembinaan koperasi sebagai unit usaha desa yang mampu meningkatkan perekonomian desa.

2. Faktor lain seperti aspek kependudukan dan permodalan dapat dianalisa lebih lanjut untuk mengidentifikasi pengaruhnya terhadap nilai output produksi suatu desa.

\section{Ucapan Terima Kasih}

Penulis mengucapkan terima kasih kepada Direktorat Riset dan Pengabdian Masyarakat, Direktorat Jenderal Penguatan Riset dan Pengembangan Kementerian Riset, Teknologi, dan Pendidikan Tinggi sebagai pihak yang telah membantu mendanai penelitian ini. Serta kepada Universitas Widyatama selaku pihak institusi yang membantu dan mendukung penulis hingga terlaksananya penelitian. 


\section{Referensi}

Amri, T. and. (2014). Provincial Competitiveness Ranking and Simulation Study for Indonesia. Annual Competitiveness Analysis and Development Strategies for Indonesian Province, 13-44.

Bappenas. (2016). Laporan Akhir Koordinasi Strategies Percepatan Pelaksanaan Pembangunan Daerah Tertinggal. Direktorat Daerah Tertinggal, Transmigrasi Dan Perdesaan, 301(5), $1163-1178$.

BPS. (2016). Provinsi Jawa Barat dalam Angka. Badan Pusat Statistik Provinsi Jawa Barat, 683. https://doi.org/32000.1601

BPS. (2017). Kabupaten Garut dalam Angka 2017. Badan Pusat Statistik Kabupaten Garut, 39(5), 561-563.

Brenneman, A., \& Kerf, M. (2002). Infrastructure \&amp; Poverty Linkages. A Literature Review", The World Bank, Washington, . Retrieved from http://ilo.org/wcmsp5/groups/public/---ed_emp/---emp_policy/--invest/documents/publication/wcms_asist_8281.pdf

Dercon, S., \& Gilligan, D. O. (2008). The Impact of Agricultural Extension and Roads on Poverty and Consumption Growth in Fifteen Ethiopian Villages. International Food Policy Research Institute, (December).

Esfahani, H. S. (2003). Institutions , infrastructure , and economic growth. Journal of Development Economics , Elsevier, 70, 443-477. https://doi.org/10.1016/S03043878(02)00105-0

Foster, V., \& Briceño-garmendia, C. (2010). Africa's Infrastructure A Time for Transformation. The International Bank for Reconstruction and Development/The World Bank.

Gnade, H., Blaauw, P. F., \& Greyling, T. (2017). The impact of basic and social infrastructure investment on South African economic growth and development. Development Southern Africa, 34 No.2(June), 347-364. https://doi.org/10.1080/0376835X.2017.1308854

McRae, S. (2015). Infrastructure quality and the subsidy trap. American Economic Review, 105(1), 35-66. https://doi.org/10.1257/aer.20110572

Ness, D. (2008). Contribution of motor vehicle emissions to surface ozone in urban areas: A case study in Beijing. International Journal of Sustainable Development \& World Ecology, 15(4), 345-349. https://doi.org/10.3843/SusDev.15.4

United Nations. (2011). Infrastructure for Economic Development and Poverty Reduction in Africa. 